\title{
SYNTHESIS, CHARACTERIZATION AND ANTIOXIDANT ACTIVITY OF 7-HYDROXY-3',4'-DIMETHOXYFLAVONE
}

\author{
Elfi Susanti VH ${ }^{1,2,}$, Sabirin Matsjeh², Tutik Dwi Wahyuningsih², \\ Mustofa $^{3}$, and Tri Redjeki ${ }^{1}$ \\ ${ }^{1}$ Department of Chemistry, PMIPA FKIP, Sebelas Maret University, Jl. Ir Sutami 36 A Surakarta Indonesia, 53126 \\ ${ }^{2}$ Department of Chemistry, Faculty of Mathematics and Natural Sciences, Universitas Gadjah Mada, \\ Jl. Sekip Utara, Yogyakarta 55281 \\ ${ }^{3}$ Faculty of Medicine, Universitas Gadjah Mada, Jl. Sekip Utara Yogyakarta 55281
}

Received November 4, 2011; Accepted December 24, 2011

\begin{abstract}
Synthesis of flavones and their derivatives has attracted considerable attention due to their significant pharmaceutical effects. 7-hydroxy-3',4'-dimethoxyflavone has been synthesized and its antioxidant activity has been investigated. Flavone was synthesized by oxidative cyclization of chalcone. 2',4'-dihydroxy-3,4-dimethoxychalcone was prepared by Claisen-Schmidt condensation of 2,4-dihydroxyacetophenones with 3,4-dimethoxybenzaldehydes in the presence of aqueous solution of sodium hydroxide and ethanol at room temperature. Oxidative cyclization of 2',4'-dihydroxy-3,4-dimethoxychalcone was done by using $I_{2}$ catalyst in DMSO to form 7-hydroxy-3', 4'dimethoxyflavone. The synthesized compounds were characterized by means of their UV-Vis, IR, ${ }^{1} H-N M R$ and ${ }^{13} \mathrm{C}$-NMR spectral data. The compound was tested for their antioxidant activities by DPPH method.
\end{abstract}

Keywords: Flavone; chalcone; Claisen-Schmidt condensation; Antioxidant activity

\begin{abstract}
ABSTRAK
Sintesis flavon dan turunannya telah menjadi penelitian yang menarik karena efek farmakologinya. 7-hidroksi3',4'-dimetoksiflavon telah disintesis dan diuji aktivitas antioksidannya. Flavon ini disintesis melalui siklisasi oksidatif senyawa kalkon. 2',4'-dihidroksi-3,4-dimetoksikalkon disintesis melalui kondensasi Claisen-Schmidt dari 2,4-dihidroksiasetofenon dengan 3,4-dimetoksibenzaldehid dalam larutan $\mathrm{NaOH}$ dan etanol pada suhu ruang. Siklisasi oksidatif 2',4'-dihidroksi-3,4-dimetokskalkon dilakukan menggunakan katalis $I_{2}$ dalam DMSO untuk membentuk 7-hidroksi-3', 4'-dimetoksiflavon. Senyawa hasil sintesis dikarakterisasi berdasarkan data spektrum UV-Vis, IR, ${ }^{1} \mathrm{H}-N M R$ dan ${ }^{13} \mathrm{C}-N M R$. Senyawa tersebut diuji aktivitas antioksidan menggunakan metode DPPH.
\end{abstract}

Kata Kunci: Flavon; kalkon; kondensasi Claisen-Schmidt; aktivitas antioksidan

\section{INTRODUCTION}

Flavones occur in nature in free state with varieties of substitution pattern. Synthesis of flavones becomes centre of attraction for many scientist because of their various physiological and pharmacological properties, such as antibacterial and antifungal [1-2], antiinflammatory [3], antimicrobial [4]. Also antioxidant, antiviral, antiproliferative, cardovascular effects of flavones have been reported in literature [5]. Having such a varied pharmacological activity and synthetic utility, flavones have attracted chemists to develop newer strategies for their synthesis.

Several strategies for the synthesis of flavones have been reported. The main synthetic methods include the Allan-Robinson Synthesis, the Baker-Venkataraman rearrangement, synthesis from chalcones, and several other more recent methods. In Allan-Robinson reaction, o-hydroxyaryl ketone was reacted with anhydride aromatic in order to form the flavone or isoflavone [6]. In Baker-Venkataraman reaction, 2-hydroxyaceto phenone was converted to ester, which then underwent rearrangement by intramolecular Claisen condensation in the presence of potassium hydroxide and pyridine to afford 1,3-diketone. This compound was then cyclised to flavone under rather harsh conditions for either by treatment with concentrated sulfuric acid or heating with glacial acetic acid [7]. Among them, oxidative cyclization of chalcones still occupies prominent position. Oxidative cyclization of 2'-hydroxychalcones constitutes an important route for the synthesis of flavones and number of oxidizing agents such as oxalic

* Corresponding author.

Email address : bunda3f@gmail.com 
acid [8], DDQ [2], microwave irradiation [9], sodium tellurite [10], and SOCI/ETOH [11] have been reported in literature for this conversion, but these often require longer reaction time, high temperature requirements, highly acidic conditions, low selectivity, toxic reagents, and formation of mixture of product containing flavones, flavanones and aurones have been reported in some cases. Although, several modifications had been made to counter these problems, there is still a need for the development of selective and better strategies for the synthesis of flavone. By using $\mathrm{I}_{2}$-DMSO as oxidizing agent in oxidative cyclization of chalcones as convenient alternative to the formation of flavone will be developed. This method were done to oxidation of 2'hydroxychalcone [12], synthesis of 2',4',6'trioxygenatedflavones [4], and 2'-oxygenated flavones [13].

The hydroxychalcone was prepared by ClaisenSchmidt condensation of 3,4-dimethoxybenzaldehydes with 2,4-dihydroxyacetophenones in the presence of aqueous solution of sodium hydroxide and ethanol at room temperature. 3,4-dimethoxybenzaldehydes was synthesized by eugenol via formation of isoeugenol and vanillin. Eugenol is main component of clove oil, abundantly present in Indonesia so this study is organic synthesis approach based on natural product. The synthesis of chalcone proceeded smoothly without protection of the hydroxy group of acetophenone to give 2',4'-dihydroxy-3,4-dimethoxychalcone. The second step, cyclization of chalcone were done efficiently by using $\mathrm{I}_{2}$-DMSO as oxidizing agent to form 7-hydroxy3',4'-dimethoxyflavone.

\section{EXPERIMENTAL SECTION}

\section{Materials}

All chemicals and solvents (2,4-dihydroxy acetophenone, 3,4-dimethoxybenzaldehyde, sodium hydroxide, ethanol, $\mathrm{HCl}$, ether, anhydrous $\mathrm{Na}_{2} \mathrm{SO}_{4}$, silica gel, lodine, dimethyl sulfoxide, EtOAc, $\mathrm{CDCl}_{3}, \mathrm{TMS}$, sodium thiosulphate, $\mathrm{KBr}$ pellets, $\mathrm{n}$-hexane, acetone) were purchased from E-Merck.

\section{Instrumentation}

Column chromatography was performed on Merck silica gel $60(0.063-0.200 \mathrm{~mm})$ to ensure homogeneity of the title compounds. Completion of reaction and purity of the final compounds were checked by TLC (E. Merck). Further, the authenticities of the compounds were established by UV-Vis, IR, ${ }^{1} \mathrm{H}-\mathrm{NMR}$ and ${ }^{13} \mathrm{C}-\mathrm{NMR}$ spectra. UV-Vis spectra was measured on spectrophotometer UV-Vis (UV, Milton Roy - Spectronic 3000). IR spectra was recorded on a Fourier-transform infrared spectrometer (Shimadzhu FTIR-8201 PC) in $\mathrm{KBr}$ pellets. ${ }^{1} \mathrm{H}-\mathrm{NMR}$ and ${ }^{13} \mathrm{C}-\mathrm{NMR}$ spectra were performed JEOL JNM ECA500 instrument using $\mathrm{CDCl}_{3}$ as solvent and Tetramethyl silane (TMS) as internal reference.

\section{Procedure}

Synthesis of 2',4'-dihydroxy-3,4-dimethoxychalcone A mixture of 2,4-dihydroxy-acetophenone $(0.01$ mole) and 3,4-dimethoxybenzaldehyde (0.01 mole) were stirred in ethanol $(15 \mathrm{~mL})$ and then an aqueous of sodium hydroxide $(12 \mathrm{~mL})$ were added. The reaction mixture was stirred at room temperature and left at room temperature for $48 \mathrm{~h}$. After that, the reaction mixture was poured into iced water, acidified with cold $\mathrm{HCl}(10 \%)$, extracted with ether $(3 \times 25 \mathrm{~mL})$. The ether layer was washed with water, followed by drying over anhydrous $\mathrm{Na}_{2} \mathrm{SO}_{4}$ and the solvent was evaporated. The reaction mixture was purified by Column chromatography on a silica gel column (n-hexane : acetone, $7: 3$ ). The product was recrystallized from ethanol as oranges needles (1.2 g; 40\%), and characterized by UV-Vis, IR, ${ }^{1} \mathrm{H}-\mathrm{NMR}$ and ${ }^{13} \mathrm{C}-\mathrm{NMR}$ Spectroscopy.

\section{Synthesis of 7-hydroxy-3',4'-dimethoxyflavone}

A solution of 2',4'-dihydroxy-3,4-dimethoxy chalcone (3 g, $0.01 \mathrm{mmole}$ ) and iodine $(250 \mathrm{mg})$ in $10 \mathrm{~mL}$ DMSO was refluxed for $1 \mathrm{~h}$. The mixture was poured into water, and the resulting syrup was extracted with EtOAc $(3 \times 15 \mathrm{~mL})$. The organic phase was washed with sodium thiosulphate solution $(20 \%)$, water and brine. The organic layer was dried over anhydrous $\mathrm{Na}_{2} \mathrm{SO}_{4}$ and the solvent was then evaporated under reduced pressure. The residual syrup was chromatographed on a silica gel column with (n-hexane : acetone, 7:3) as eluen and the compound purified by recristalized from ethanol as yellow needles $(0.2 \mathrm{~g} ; 33 \%)$. The product was characterized by UV-Vis, IR, ${ }^{1} \mathrm{H}$ NMR and ${ }^{13} \mathrm{C}$ NMR Spectroscopy.

\section{Antioxidant activity of Compounds was performed by DPPH method}

The various concentrations of Compounds (200, 220, 240, 400, $500 \mu \mathrm{g} / \mathrm{mL}$ ) were prepared. Stock solution of DPPH $0.4 \mathrm{mM}$ in ethanol was prepared. $50 \mu \mathrm{L}$ samples add with $1.0 \mathrm{~mL}$ solution of DPPH and $3.95 \mathrm{~mL}$ of ethanol. After vortexing, the mixture was incubated for $30 \mathrm{~min}$ at room temperature and the absorbance at $517 \mathrm{~nm}$ was measured. The difference in absorbance between a test sample $(50 \mu \mathrm{L}$ extract and $4.95 \mathrm{~mL}$ ethanol) and control $(1.0 \mathrm{~mL}$ and $4.0 \mathrm{~mL}$ ethanol) was considered as activity. The activity was shown as $\mathrm{IC}_{50}$ value. All values are shown as mean of 
<smiles>CC(=O)c1ccc(O)cc1O</smiles><smiles>COc1ccc(C=O)cc1OC</smiles>

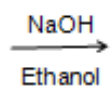<smiles>COc1ccc(/C=C/C(=O)c2ccc(O)cc2O)cc1OC</smiles>

(1)<smiles>COc1ccc(-c2cc(=O)c3ccc(O)cc3o2)cc1OC</smiles>

Fig 1. Synthesis of 7-hydroxy-3',4'-dimethoxyflavone

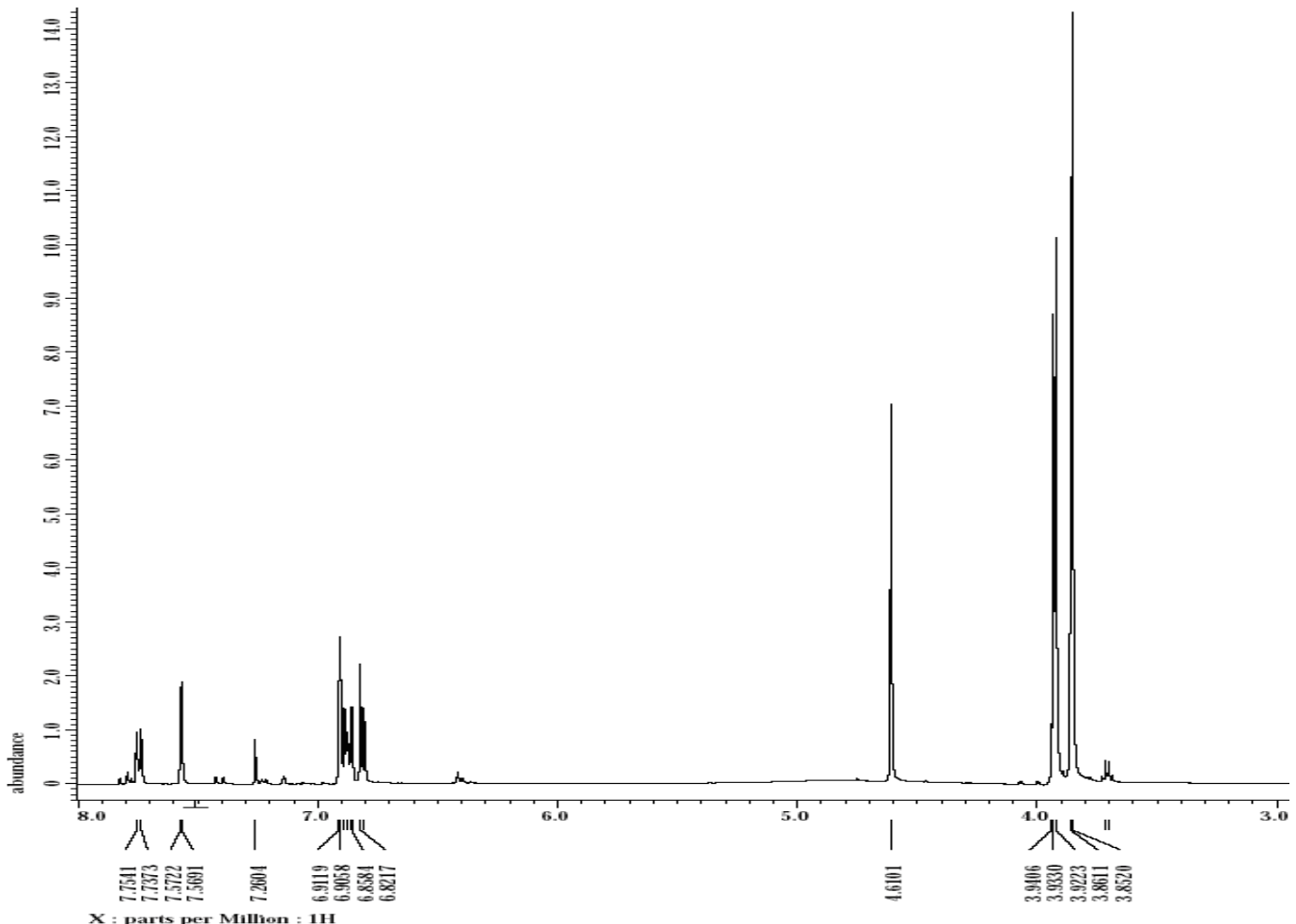

Fig 2. ${ }^{1} \mathrm{H}-\mathrm{NMR}$ Spectrum of 2',4'-dihydroxy 3,4-dimethoxychalcone

three measurements. $\%$ Inhibition $=[$ A Control $-\mathrm{A}$ Test $]$ I A Control $\times 100$. [14]

\section{RESULT AND DISCUSSION}

The synthetic approach to 7-hydroxy-3',4'dimethoxyflavone (2) is as illustrated in Fig. 1. The Claisen-Schmidt condensation of 2,4-dihydroxy acetophenone with commercially available 3,4dimethoxybenzaldehyde under basic condition $(\mathrm{NaOH}$ $50 \%$ ) in ethanol proceeded smoothly to furnish 2 ', 4 '- dihydroxy-3,4-dimethoxychalcone (1) (40\%). The compound was obtained as yellow-needle crystals and it gave orange color with $\mathrm{Mg} / \mathrm{HCl}$. The structure of this compound was confirmed by spectral data.

Spectral data, UV-Vis (nm): 211, 231, 278, 310; IR $\left(\mathrm{KBr}, \mathrm{cm}^{-1}\right)$ : 3410, 3086, 2939, 1674, 1589, 1512, 1465,$1265 ;{ }^{1} \mathrm{H}$ NMR $\left(\mathrm{CDCl}_{3}\right): \delta 3.85\left(3 \mathrm{H}, \mathrm{C} 3-\mathrm{OCH}_{3}\right)$, $3.86\left(3 \mathrm{H}, \mathrm{C} 4-\mathrm{OCH}_{3}\right), 4.6(\mathrm{OH}) .7 .5(1 \mathrm{H}, \mathrm{H}-\alpha), \delta 7.7(1 \mathrm{H}$, $\mathrm{H}-\beta), 6.90(1 \mathrm{H}, \mathrm{H}-5), 6.91(1 \mathrm{H}, \mathrm{H}-2), 7.2(1 \mathrm{H}, \mathrm{H}-6) ;{ }^{13} \mathrm{C}-$ NMR $\left(\mathrm{CDCl}_{3}\right)$ : $\delta 171(\mathrm{C}=\mathrm{O}), 153.6\left(\mathrm{C}-4^{1}\right), 149.1\left(\mathrm{C}-2^{1}\right)$, 148.7 (C-4), 148.6 (C-3), 121.9 (C-1), $111.1\left(\mathrm{C}-1^{1}\right)$, 


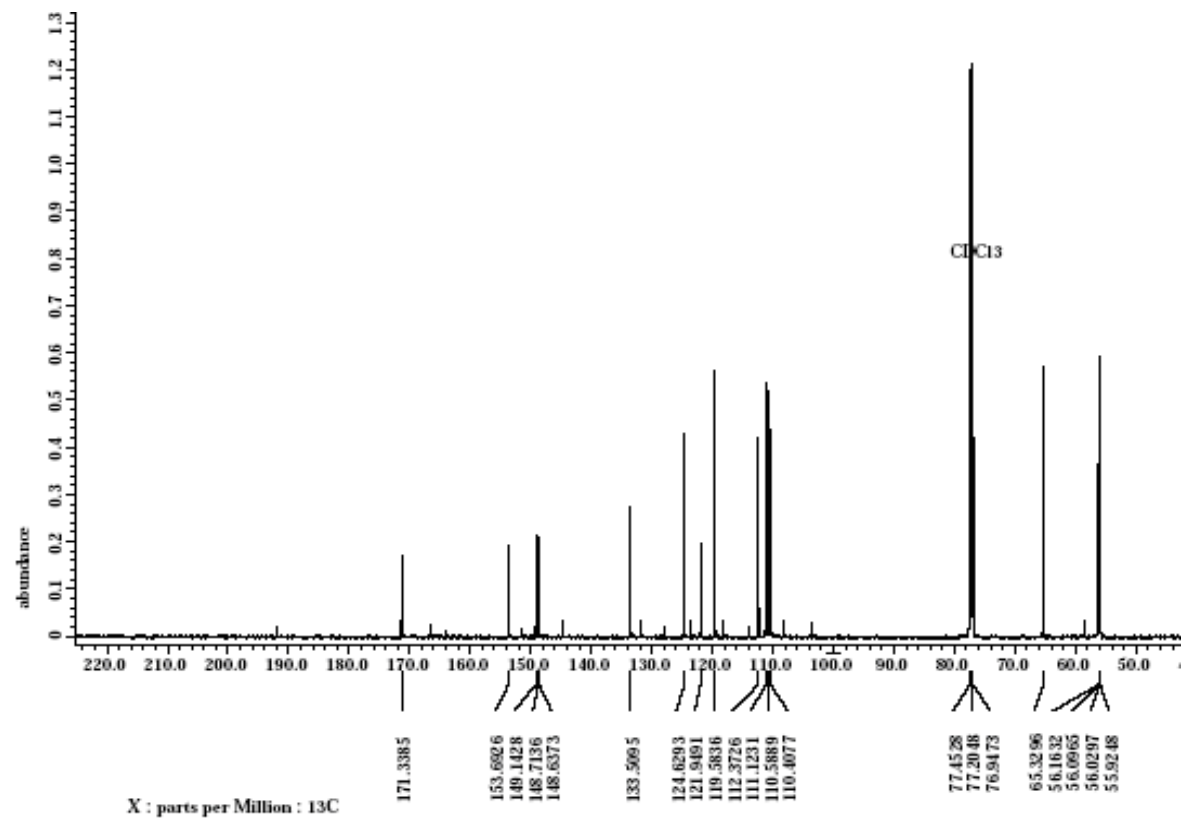

Fig 3. ${ }^{13} \mathrm{C}-\mathrm{NMR}$ Spectrum of 2',4'-dihydroxy-3,4-dimethoxychalcone

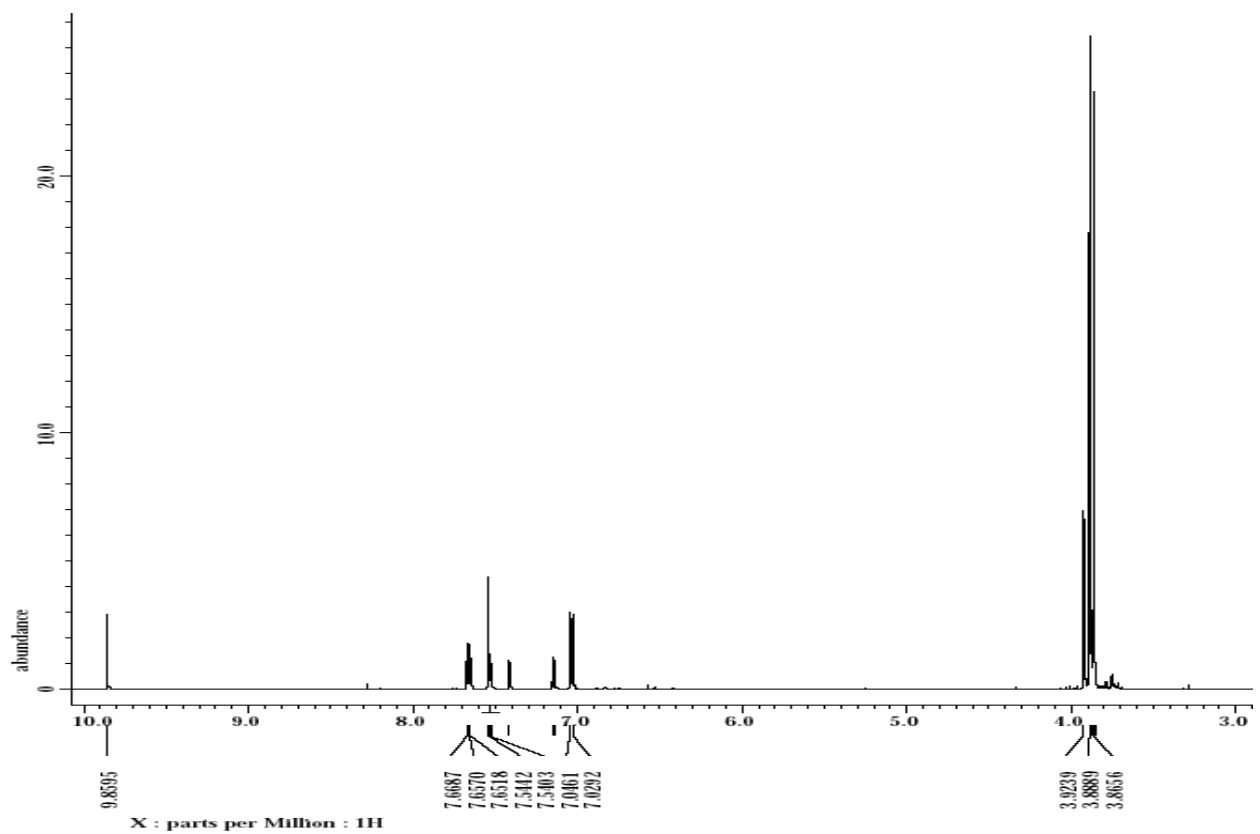

Fig 4. ${ }^{1} \mathrm{H}-\mathrm{NMR}$ Spectrum of 7-hydroxy-3',4'-dimethoxyflavone

$133.5(\mathrm{C}-\beta), 119.5(\mathrm{C}-\alpha), 124.6\left(\mathrm{C}-6^{1}\right), 112.3(\mathrm{C}-6)$, 110.5 (C-5), 110.4 (C-2), $65.3\left(\mathrm{C}-5^{1}\right), 56.1\left(\mathrm{C}-3^{1}\right), 56.02$ $\left(\mathrm{CH}_{3}\right)$.

The UV-Vis absorbance band of this compound $\left(\lambda_{\max } 211,231,278,310\right)$ suggested the presence of a chalcone skeleton. The IR absorption spectrum band at $3410 \mathrm{~cm}^{-1}$ indicated that the presence of hydroxyl group, and a band at $1674 \mathrm{~cm}^{-1}$ and $1589 \mathrm{~cm}^{-1}$ showed the presence of a conjugated carbonyl group.
The ${ }^{1} \mathrm{H}-\mathrm{NMR}$ spectrum of compound (Fig. 2) explained the presence of two methoxyl groups in the B-ring at $\delta 3.85$ and 3.86, integrating for 12 protons. The phenolic $-\mathrm{OH}$ signal was observed at $\delta$ 4.6. The olefinic proton of $\alpha, \beta$-unsaturated ketone were clearly observed at $\delta 7.5(1 \mathrm{H}, \mathrm{H}-\alpha)$ and $\delta 7.7(1 \mathrm{H}, \mathrm{H}-\beta)$ corresponding to $\mathrm{H}-\alpha$ and $\mathrm{H}-\beta$. The three aromatic protons of the B-ring were observed at $\delta 6.90$ $(1 \mathrm{H}, \mathrm{H}-5), \delta 6.91(1 \mathrm{H}, \mathrm{H}-2), \delta 7.2(1 \mathrm{H}, \mathrm{H}-6)$. 


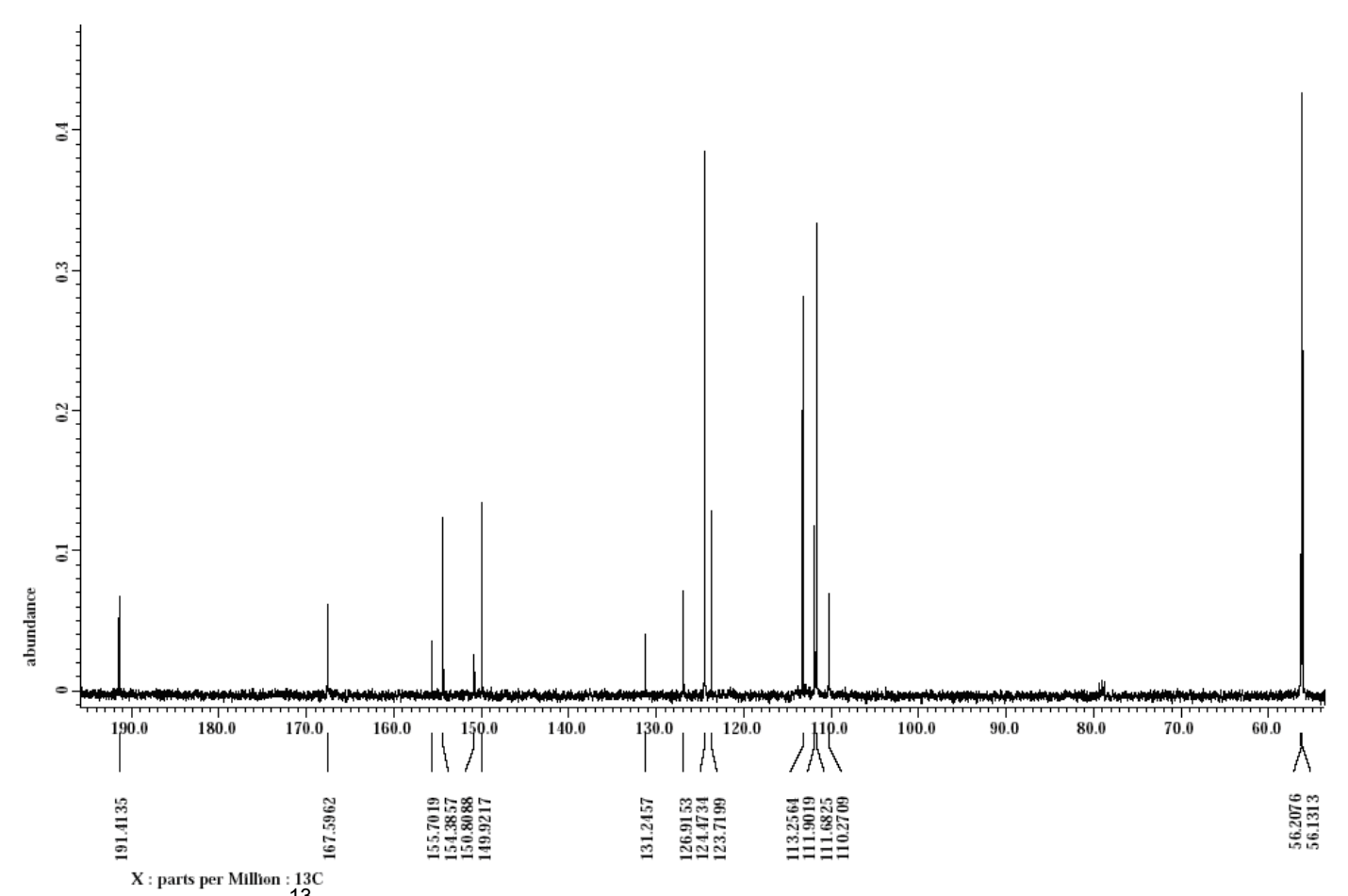

Fig 5. ${ }^{13} \mathrm{C}-\mathrm{NMR}$ Spectrum of 7-hydroxy-3',4'-dimethoxyflavone

The ${ }^{13} \mathrm{C}-\mathrm{NMR}$ spectrum of chalcone (Fig. 3) showed the presence of 17 different carbons. The signals for one carbonyl at $\delta 171$, and signals for methyl carbons at $\delta 56.0$. The spectrum indicated the presence six quarternary carbon at $\delta 153.6\left(\mathrm{C}-4^{1}\right), 149.1\left(\mathrm{C}-2^{1}\right)$, 148.7 (C-4), 148.6 (C-3), $121.9(\mathrm{C}-1), 111.1\left(\mathrm{C}-1^{1}\right)$, and eight methine carbons at $\delta 133.5(\mathrm{C}-\beta), 119.5(\mathrm{C}-\alpha)$, $124.6\left(\mathrm{C}-6^{1}\right), 112.3$ (C-6), 110.5 (C-5), 110.4 (C-2), 65.3 $\left(\mathrm{C}-5^{1}\right), 56.1\left(\mathrm{C}-3^{1}\right)$, and two methoxy carbons at $\delta 56.02$. Based on the above spectral evidences, it can be concluded that compound (1) characterized as 2',4'dihydroxy-3,4-dimethoxychalcone.

The second sequence in synthesis required the cyclization of 2',4'-dihydroxy-3,4-dimethoxychalcone into 7-hydroxy-3',4'-dimethoxyflavone. Cyclization was carried out by using iodine in DMSO as catalyst. The compound was obtained as yellow-needle crystals and it gave orange color with $\mathrm{Mg} / \mathrm{HCl}$. The formation of flavone was supported by spectral data.

Spectral data; UV-Vis $(\mathrm{nm}): 261,287 \mathrm{~nm}$; IR $(\mathrm{KBr}$, $\left.\mathrm{cm}^{-1}\right)$ : 3402, 1674, 1589, 1512, 1265; ${ }^{1} \mathrm{H}$ NMR $\left(\mathrm{CDCl}_{3}\right)$ : ס $7.02(1 \mathrm{H}, \mathrm{s}, \mathrm{H}-3), 7.544\left(\mathrm{H}-2^{1}\right), 7.65\left(\mathrm{H}-5^{1}\right), 7.66(\mathrm{H}-$ $\left.6^{1}\right), 7.04(\mathrm{H}-8), 7.540(\mathrm{H}-6), 9.8(\mathrm{H}-5) ;{ }^{13} \mathrm{C}-\mathrm{NMR}\left(\mathrm{CDCl}_{3}\right)$ : ठ $191.4(\mathrm{C}=\mathrm{O}), 56.2\left(\mathrm{CH}_{3}\right), 167.59(\mathrm{C}-2), 155.7(\mathrm{C}-7)$, 154.3 (C-8a), $150.8\left(\mathrm{C}-3^{1}\right), 149.9\left(\mathrm{C}-4^{1}\right), 126.9\left(\mathrm{C}-1^{1}\right)$, 123.7 (C-4a), 131.2 (C-5), 124.47 (C-6 $\left.{ }^{1}\right), 113.2$ (C-2 $\left.{ }^{1}\right)$, $111.9\left(\mathrm{C}-5^{1}\right), 111.6(\mathrm{C}-6), 110.27$ (C-8), 56.34 (C-3), $56.2\left(\mathrm{C}^{1}-\mathrm{OCH}_{3}\right), 56.1\left(\mathrm{C}^{1}-\mathrm{OCH}_{3}\right)$.

The UV spectrum of the compound displayed absorption bands at 261 and $287 \mathrm{~nm}$ suggested the presence of a flavone skeleton. The IR spectrum of compound displayed bands absorption for $-\mathrm{OH}$ $\left(3402 \mathrm{~cm}^{-1}\right)$. The absorption bands at $1674 \mathrm{~cm}^{-1}$ as well as 1589 and $1512 \mathrm{~cm}^{-1}$ indicating the presence of a conjugated carbonyl group and aromatic rings respectively. The presence of $\mathrm{C}-\mathrm{O}$ is indicated by the absorption at $1265 \mathrm{~cm}^{-1}$. In the ${ }^{1} \mathrm{H}$ NMR spectrum (Fig. 4), the absence of a phenolic proton signal at upfield region was noted; indicating that the oxidative cyclization of chalcone has took place. This is also supported by the presence of a characteristic singlet signal for a flavone at $\delta 7.02(1 \mathrm{H}, \mathrm{s}, \mathrm{H}-3)$. The aromatic protons of $B$ ring at $\delta 7.544\left(\mathrm{H}-2^{1}\right), 7.65\left(\mathrm{H}-5^{1}\right)$, and $7.66\left(\mathrm{H}-6^{1}\right)$. Whereas the three aromatic proton of the ring $A$ appeared at $\delta 7.04(\mathrm{H}-8), 7.540(\mathrm{H}-6)$ and 9.8 $(\mathrm{H}-5)$.

The ${ }^{13} \mathrm{C}-\mathrm{NMR}$ spectrum of flavone (Fig. 5) showed the presence of 17 different carbons. The signals for one carbonyl at $\delta 191.4$, and signals for methyl carbons at $\delta 56.2$. The spectrum indicated the presence seven quarternary carbon at $\delta 167.59$ (C-2), 155.7 (C-7), 154.3 (C-8a), 150.8 (C-3 $\left.{ }^{1}\right), 149.9\left(\mathrm{C}-4^{1}\right)$, $126.9\left(\mathrm{C}-1^{1}\right), 123.7(\mathrm{C}-4 \mathrm{a})$ and seven methine carbons at $\delta \quad 131.2 \quad(\mathrm{C}-5), 124.47 \quad\left(\mathrm{C}-6^{1}\right), 113.2 \quad\left(\mathrm{C}-2^{1}\right)$, $111.9\left(\mathrm{C}-5^{1}\right), 111.6$ (C-6), 110.27 (C-8), 56.34 (C-3), and two methoxy carbons overlapping at $\delta 56.1$. Based on the above spectral evidences, it can be concluded that compound (2) characterized as 7-hydroxy-3',4'dimethoxyflavone. 
In this study, the antioxidant activities of the synthesized compounds were measured using $\mathrm{DPPH}$ method. The DPPH radical scavenging assay has been widely used to assess the antioxidant ability of compounds. This method is based on the ability of DPPH radical to react with hydrogen donor species such as phenolics and flavonoids present in the extract material. Upon receiving a proton from the donor species it loses its color and becomes yellow. As the concentration of phenolic compounds increases their DPPH radical scavenging activity also increases.

The free radical scavenging activity of compound was investigated with $I_{50}$ (the extract concentration inhibiting $50 \%$ of DPPH radicals). Both of compound 2',4'-dihydroxy-3,4-dimethoxychalcone and 7-hydroxy3',4'-dimethoxyflavone tested showed low radical scavenging activity with $\mathrm{IC}_{50}$ more than $100 \mu \mathrm{g} / \mathrm{mL}$.

\section{CONCLUSION}

7-hydroxy-3',4'-dimethoxyflavone has been synthesized by oxidative cyclization of 2',4'-dihydroxy3,4-dimethoxychalcone. The synthesized compounds were characterized by UV-Vis, IR, ${ }^{1} \mathrm{H}-\mathrm{NMR}$ and ${ }^{13} \mathrm{C}-\mathrm{NMR}$ spectroscopy. The result obtained from this research confirmed that the product had been formed. $\mathrm{IC}_{50}$ (the extract concentration inhibiting $50 \%$ of $\mathrm{DPPH}$ radicals) values for this compound more than $100 \mu \mathrm{g} / \mathrm{mL}$, showed that this compound was not active as an antioxidant.

\section{ACKNOWLEDGEMENT}

The authors are thankful to DP2M Dikti and Head of LPPM UNS, head of NMR Laboratory LIPI Jakarta, Organic Laboratory UGM, and Chemistry Laboratory PMIPA FKIP UNS.

\section{REFERENCES}

1. Murthy, Y.L.N., Viswanath, I.V.K., and Pandit, E.N., 2010, Int. J. ChemTech Res., 2, 2, 1097-1101.

2. Mostahar, S., Katun, P., and Islam, A., 2007, J. Biol. Sci., 7, 3, 514-519.

3. Theja, D.N., Choudary, T.P., Reddy, M.I., Avss, G., and Reddy, K.U., 2011, Int. J. Pharm. Pharm. Sci., 3, 2, 51-54.

4. Alam, S., and Mostahar, S., 2005, J. Appl. Sci., 5, 2, 327-333.

5. Middleton, E.Jr., Kandaswami, C., and Theoharides, T.C., 2000, Pharmacol. Rev., 52, 4, 673-751.

6. Ares, J.J., Outt, P.E., Kakodkar, S.V., Buss, R.C., and Geiger, J.C., 1993, J. Org. Chem., 58, 27, 7903-7905.

7. Ganguly, A.K., Kaur, S., Mahata, P.K., Biswas, D., Pramanik, B.N., and Chan, T.M., 2005, Tetrahedron Lett., 46, 23, 4119-4121.

8. Zambare, A.S., Sangshetti, J.N., Kokare, N.D., and Shinde, D.B., 2009, Chin. Chem. Lett., 20, 2, 171174.

9. Kabalka, G.W., and Mereddy, A.R., 2005, Tetrahedron Lett., 6, 37, 6315-6317.

10. Kumar, S., and Sharma, D., 2011, Orient. J. Chem., 27, 2, 761-763.

11. Jayapal, M.R., Prasad, K.S., and Sreedhar, N.Y., 2010, Int. J. Pharm. Biol. Sci., 1, 4, 361-366.

12. Doshi, A.K., Soni, P.A., and Ghiya, B.J., 1986, Indian J. Chem., 258, 759.

13. Mostahar, S., Alam, S., and Islam, A., 2006, J. Serb. Chem. Soc., 72, 4, 321-329

14. Tagashira, M., and Ohtake Y., 1998, Planta Med., $64,555-558$. 